\title{
The Impact of Ownership Structure on Financial Performance; A Comparison Study of Two Chinese Banks
}

\author{
Juliana Stanley Isanzu \\ School of Management, Wuhan University of Technology, Wuhan, China \\ Email : julianaisanzu@yahoo.com
}

\begin{abstract}
Interest on the effect of ownership structure and financial performance has grown much, yet researchers have provided mixed results. This study aims at investigating the relationship between state-owned and joint venture type of ownership structures by testing whether or not there is a difference in their performance. The study used quantitative methods to find out if there is a significance difference in performance of two types of firms namely State Owned and Joint venture. The variables used were Return on asset, Return on Equity, Capital Adequacy, Nonperforming Loans and Earnings per Share. Further, T-test was used to test the difference in performance of the two types of firms. The results have revealed that there is no significant difference in performance between the two types of ownership structure. Statistically, the performance of state-owned and joint ventures is the same. This means the efforts to radicalize the state-owned companies have paid off by eliminating the impact of ownership structure on financial performance of the firm.
\end{abstract}

Keywords: Ownership Structure, Financial Performance, Banks, State Owned Enterprise (SOEs)

\section{Introduction}

Does privatization free companies from political influence? Certainly not, there are still ways by which the government can interfere with the management and decision making of the firm if the laws and regulations of the country do not support independence, transparency and non-interference by state political interests. Besides, privatization without the supporting regulatory and supervisory body can lead to a crisis. The Chinese government has continued to privatize State Owned Enterprise (SOEs) gradually to fund its expansion projects and increase their efficiency through management buyouts and going public by listing.

It is a myth that SOEs are inefficient created to serve only social and political purposes rather than to cater for the economic development. It is said that their primary goal is not to maximize shareholders wealth like the normal goal of a firm. The mere fact that SOEs are under the government control, the government has the power to distort the policy objectives whenever they see fit. The importance of banking and financial sector development is proven to be very crucial to the country's economic growth. Several literature have found the financial sector to be the driver of increased income and growth in the country. Therefore, so many countries have been restructuring and privatizing their banks for efficient and improved performance.

Some of the important reforms on SOEs focused on management responsibility system by delegating decision-making rights to the directors, separation of ownership and management authority by giving the management autonomy and performance evaluation measures put in place (Chuo and Huang, 2010). This paper seeks to unveil the relationship by finding if there is a difference in performance of the two types of firms. Despite wide research of the subject matter, empirical evidence has provided mixed results. 


\section{Literature Review}

\section{Ownership Structure}

Company ownership structure is now in line with corporate governance and it has become an important that issue of the enterprise reforms started in the late of 1970s. China has become the fastest growing economy in the world within this recent decade. It is generally accepted that the great economic success is achieved through the economic reform. One of the most impressive phenomena has been the relative decline of state-owned companies and the rise of private sectors (Ding et al, 2007).

\section{Firm's Financial Performance}

This is a subjective evaluation of how well a firm can use assets from its primary mode of business and generate revenues. The term is also used as a general measure of a firm's general financial health over a given period of time, and can be used to compare similar firms within the same industry or to compare industries or sectors in aggregate (Fauzi, 2007). Boubakri et al. (2005) found arguments favoring state-owned banks, that private banks are exposed to a crisis, they have limited access to finance, and that the government is more fitted to allocate capital for investments. Some of the development theory views the government ownership as a necessary means to trigger economic and financial development, especially, for countries that have underdeveloped economic institutions and government finance projects with social benefits.

The political view supports that government actions are to provide employment, return the benefits of supporter's votes, and make social contributions; this is most commonly practiced in underdeveloped financial systems with poorly developed property rights. There is evidence that party interference is negatively correlated with company performance claiming that non-state shareholders reduce political interference thus improving company financial performance of listed firms. Monitoring and control over investments are more effective for the non-state enterprises thus face less loss in performance. In SOEs the government acts as the largest shareholder and regulatory body thus serves two conflicting roles and the question is whether it can effectively enforce the law and control fraud.

Study by Wang and Xiao (2009) found that there is a negative relationship between firm value and government control but their study revealed that as the control rights are decentralized in the SOE, performance is improved as well as firm value. Many researchers believe that inefficiency of SOEs happens due to property rights in the private sector are more defined that in the public sector, giving the management incentives to seek more profits leading to more effective monitoring of management performance. According to the Agency theory by Meckling (1976), if managers act in the interests of shareholders, they are supposed to maximize shareholders' wealth, as their primary goal by choosing to undertake projects with higher risk thus higher return. Such a risk shifting behavior is disadvantageous to creditors' interests, unless these are able to effectively monitor managers. Banks in general are higher leveraged when compared to non-financial firms which allow them to take higher risks, as shareholders may get more incentives to shift high levels of risk. According to agency theory, risk taking behavior is influenced is caused by the conflicts of interest between managers and shareholders (Jensen and Meckling, 1976). Instead of maximizing shareholders' wealth, managers can sometimes pursue their own interests, by enjoying private benefits of control or preserving specific acquired human capital which is not the case with state-owned banks.

In addition, managers bear the specific risk of the firms they manage, since some of the incentives and job security depend on their performance and thus they are expected to be more risk averse than shareholders with a diversified investment portfolio which may not be affected to much in case the investments do not pay back. Such systems help to converge the interests of shareholders and managers as managers' shareholdings increases, resulting in more risk taking. While if managers' equity ownership is increased it provides them with voting power sufficient to pursue personal objectives, resulting in less risk taking, expropriation of shareholders, and entrenchment. State ownership is deemed inefficient due to lack of monitoring which leaves managers in pursuant of their interests, they are not punished for inefficiencies and they have no pressures from outside environment. Investors value transparency, they tend to have confidence when the firm informs the public about all important management decisions to be made and why they were made.

Wei and Varela, (2003) found that firm size and strategic industry are determinants of State Ownership. Ng et al, (2009) found that on strategic important industries like mining and exploitation there is a positive relationship between 
performance and state ownership. Claiming initially State Ownership has a negative effect on performance but after a certain level it becomes positive. When firms have diverse ownership structures it creates the free rider problem, no incentives or resources to monitor and control the management. Xu and Wang, (2006) used market-based ratios, return on asset and return on equity they found that there is a positive relationship between performance and legal person shares. Sun and tang (2003) found that state ownership has a negative impact on firm performance, while a legal person has a positive impact on firm performance after presentation. $\mathrm{Ng}$ et al, (2009) using Tobin q, return on asset, return on equity found a convex relationship between state ownership and performance suggesting that there is a strong relationship between performance and state control. This is because of the reduced risk in taking projects since incentives are not attached to the management performance. Berger at al, (2005) found that public banks are less profitable because they have more costs, less asset quality compared to private banks. This is because they have a large number of workers who can sometimes over burden the firm with high rates of job turnover and other costs of employee and this leads to them being inefficient.

\section{Data and Methodology}

Bank financial statement for the time period of 2005-2013 from the bank's website is used to obtain the data for the variables. The participating banks are Bank of China (SOE) and China Citic Bank (JVC). The ownership type is read from the company profile in the annual report. Data from these two banks which one state-owned and the other joint venture will be used. Ownership type will be measured by a dummy variable. The variables for performance are Return on Asset, Return on Equity, Capital adequacy, Non-performing loans and Earnings per Share. The performance of the two banks will be compared using independent sample T-test. The analysis will be done using SPSS 16.0.

\section{Findings and Discussion}

This section presents and comments on the figures, descriptive statistics, results of the t-test analysis and their interpretations. The section will start with the figures for all the variables used in a yearly basis compared for Joint Ventures vs State Owned, then the summary of descriptive statistics especially the means and finally what the independent sample t test tells us about the two types of firms whether there is a difference in their performance.

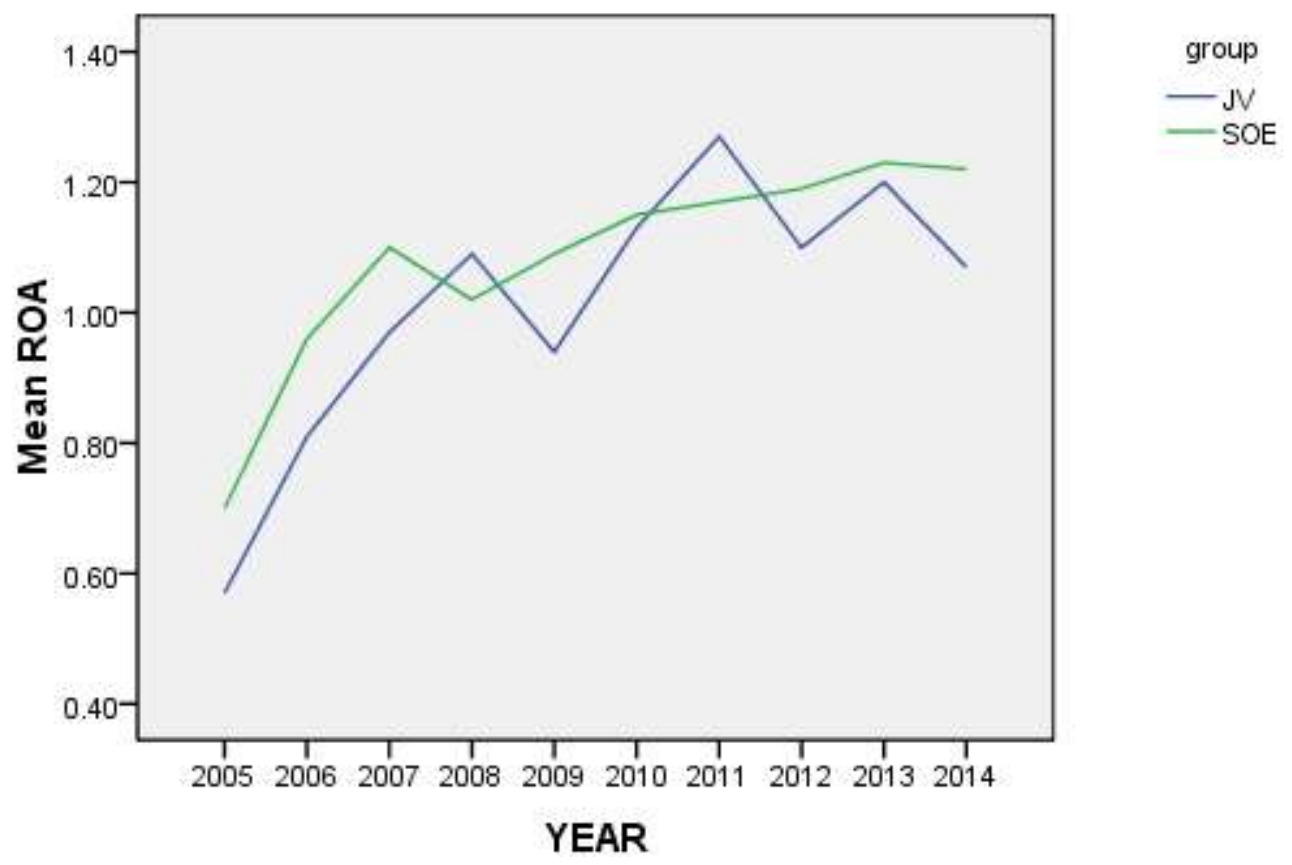

Figure 1: Return on Asset of Joint venture vs. State Owned firm

From figure 1, it can be observed that the return on asset performance of joint venture is fluctuating a lot while that of State Owned is on a more steady increment. It is hard though to tell which company is performing better but we can see that in 2012, State-owned performance has risen to surpass that of a joint venture. 


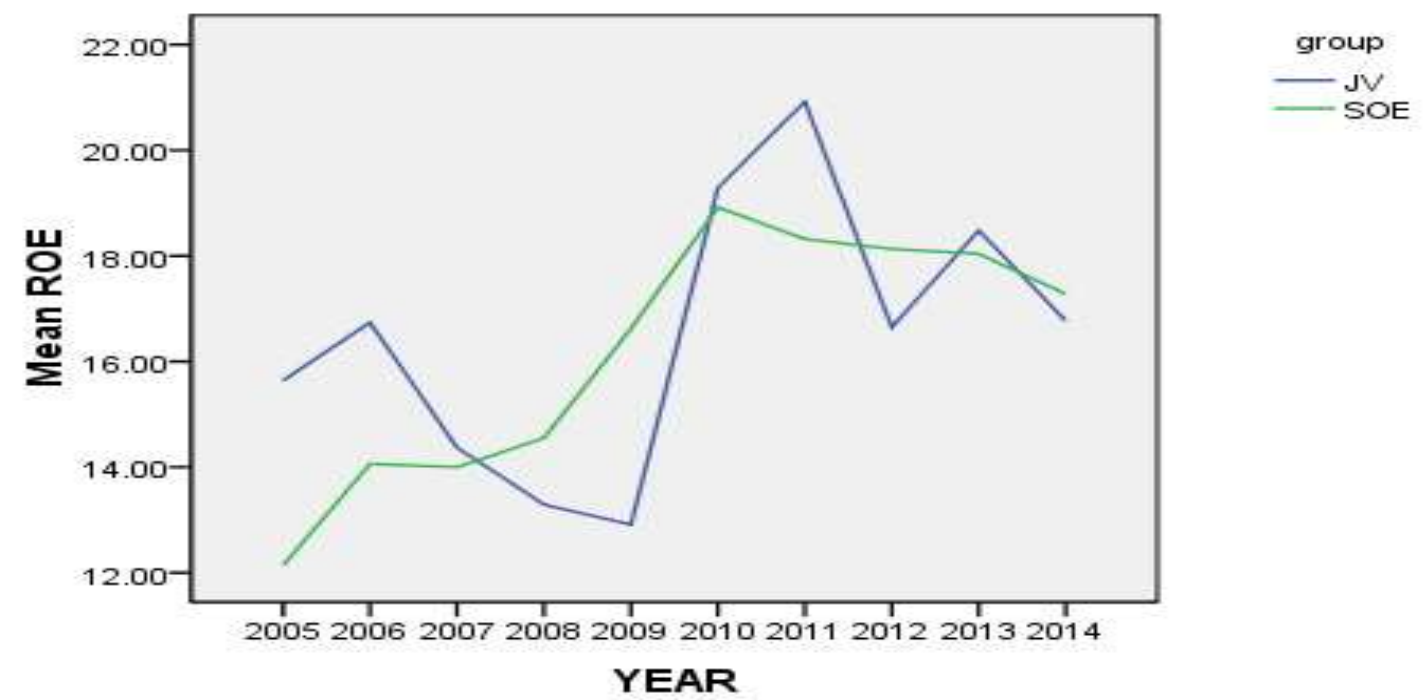

Figure 2: The Figure of Return on Equity of Joint venture vs. State-Owned Firm

From figure 2, it can be observed that the performance of Joint Venture and State Owned have been exhibiting a similar pattern, though it is very hard to tell who is performing better but we can see that a sharp rise in performance between 2008 and 2010 and then a decline in 2014. Both types of a company their performance has declined with SOE slightly above Joint Venture.

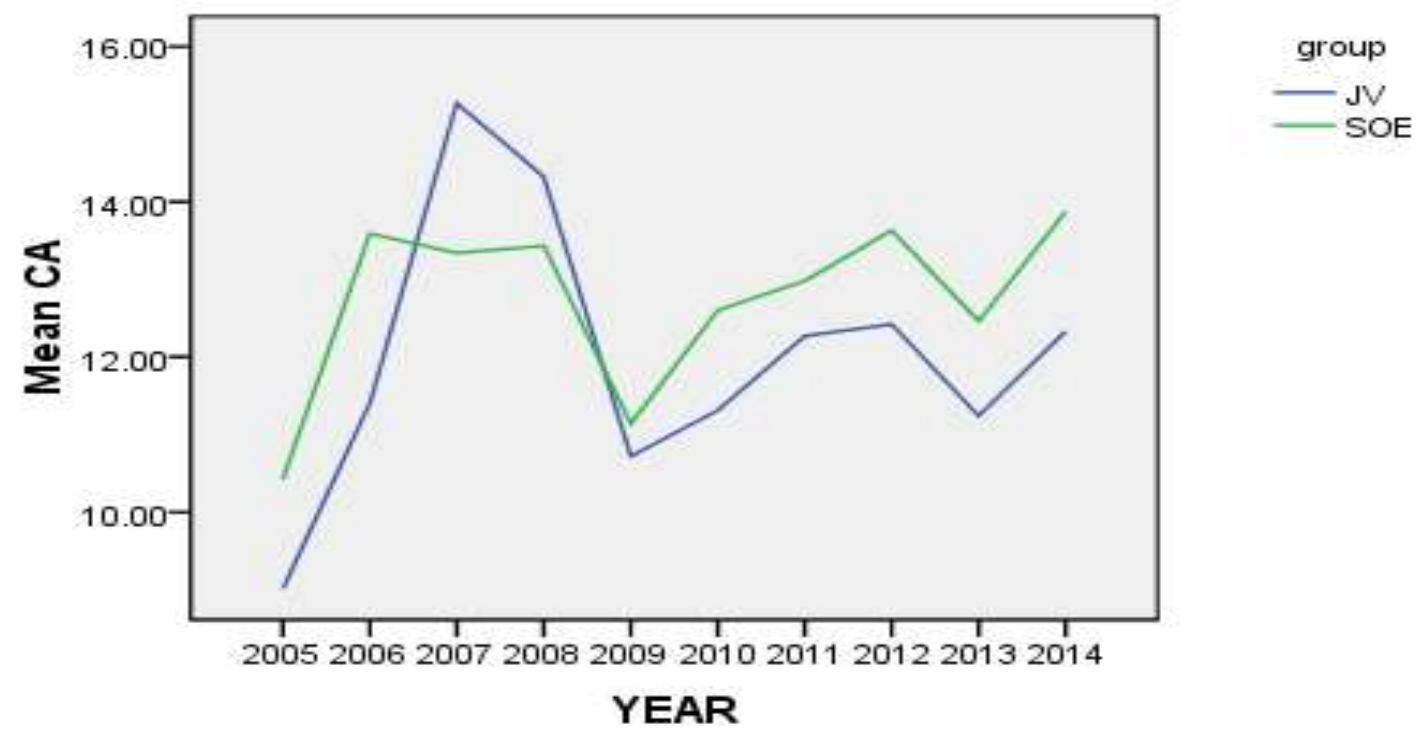

Figure 3: The figure of Capital Adequacy of Joint Venture vs. State-Owned Firm

From the above figure we can be observed that the capital adequacy ratio for both types of a company has been having some major fluctuations in the year 2005 to 2009. In 2013 they had both started to increase again with State Owned having a higher capital adequacy ratio than that of Joint Venture. 

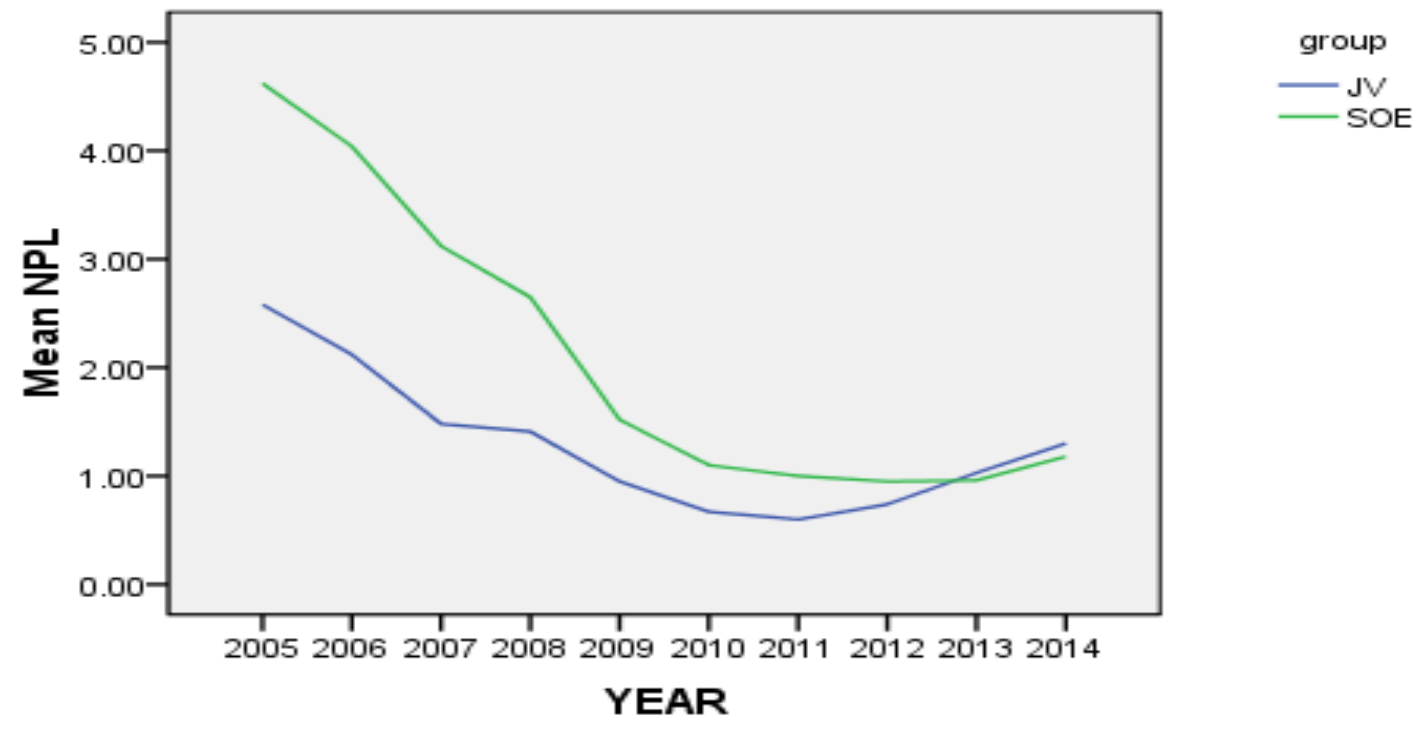

Figure 4: The Figure on Non-Performing Loans of Joint Venture vs. State-Owned Firm

From figure 4, we observe that nonperforming loans have been declining at a similar rate for both types of firms and initially State Owned had a very high non-performing ratio than joint venture but in 2011 the nonperforming loan ratio has started to increase again with joint venture slightly higher than state owned.

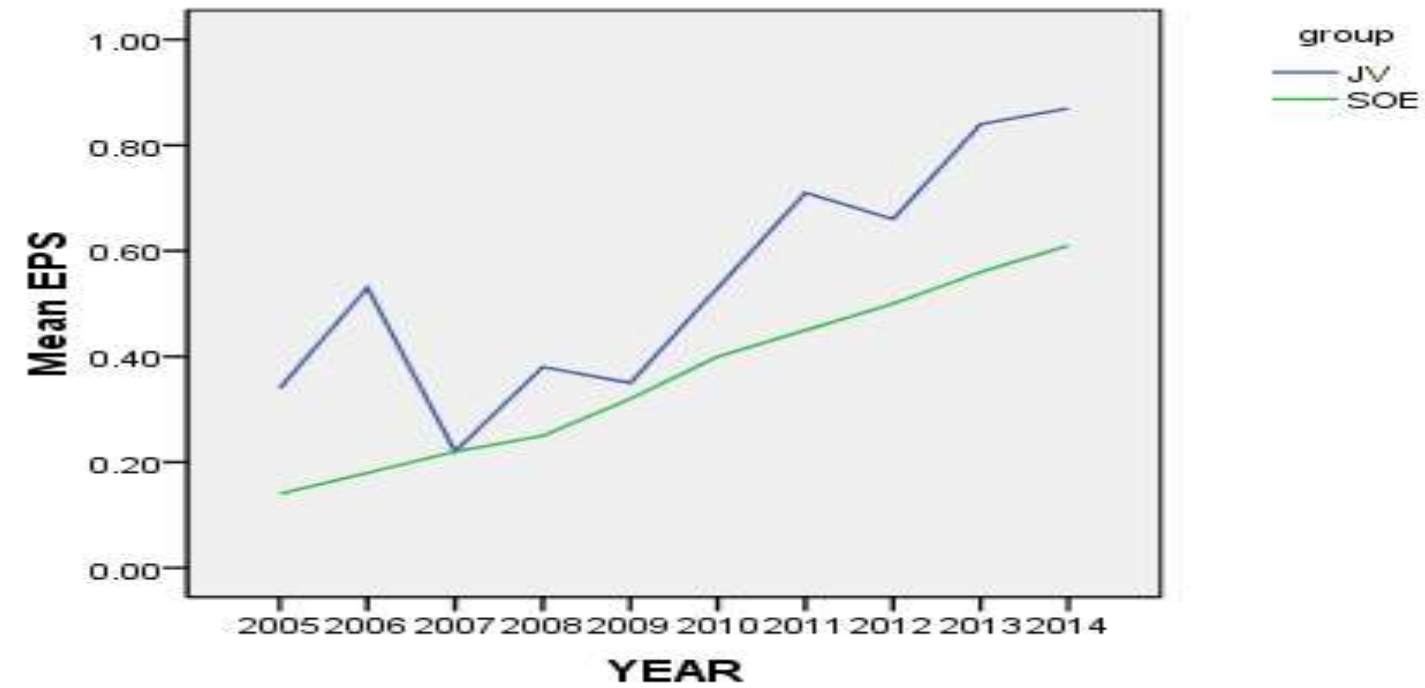

Figure 5: the Figure on Earnings per Share of Joint Venture vs. State-Owned Firm

From figure 5 we can observe that the earnings per share of the Joint Venture has been fluctuating a lot throughout the year but in an increasing rate, while that of State Owned has been having a steady and smooth increment throughout the year. We can see that Joint Venture share is performing better than that of State Owned. 
Juliana Stanley Isanzu

The Impact of Ownership Structure on Financial Performance; A Comparison Study of Two Chinese Banks

Table 1: Group Statistics

\begin{tabular}{|ll|r|r|r|r|}
\hline & Group2 & $\mathrm{N}$ & Mean & Std. Deviation & \multicolumn{1}{c|}{ Std. Error Mean } \\
\hline ROA & 1 & 10 & 1.0830 & .15986 & .05055 \\
& 2 & 10 & 1.0150 & .20441 & .06464 \\
\hline ROE & 1 & 10 & 16.2060 & 2.33265 & .73765 \\
& 2 & 10 & 16.5060 & 2.57902 & .81556 \\
\hline NPL & 1 & 10 & 2.1140 & 1.39323 & .44058 \\
& 2 & 10 & 1.2880 & .64548 & .20412 \\
\hline EPS & 1 & 10 & .3630 & .16526 & .05226 \\
& 2 & 10 & .5430 & .22271 & .07043 \\
\hline
\end{tabular}

From the above table, it is observed that the mean of Joint venture ROA 1.083 is higher than that of State Owned 1.015, the mean ROE of State Owned 16.506 is higher than that of Joint Venture 16.206 the mean NPL of Joint Venture 2.114 is higher than that of State Owned 1.288 and the mean EPS of State Owned 0.5430 is higher than that of Joint Venture 0.363. From this stage is important to find out if the differences of these means are statistically significant or not. That is why we go further buy carrying out a t-test.

Table 2: Independent Samples Test

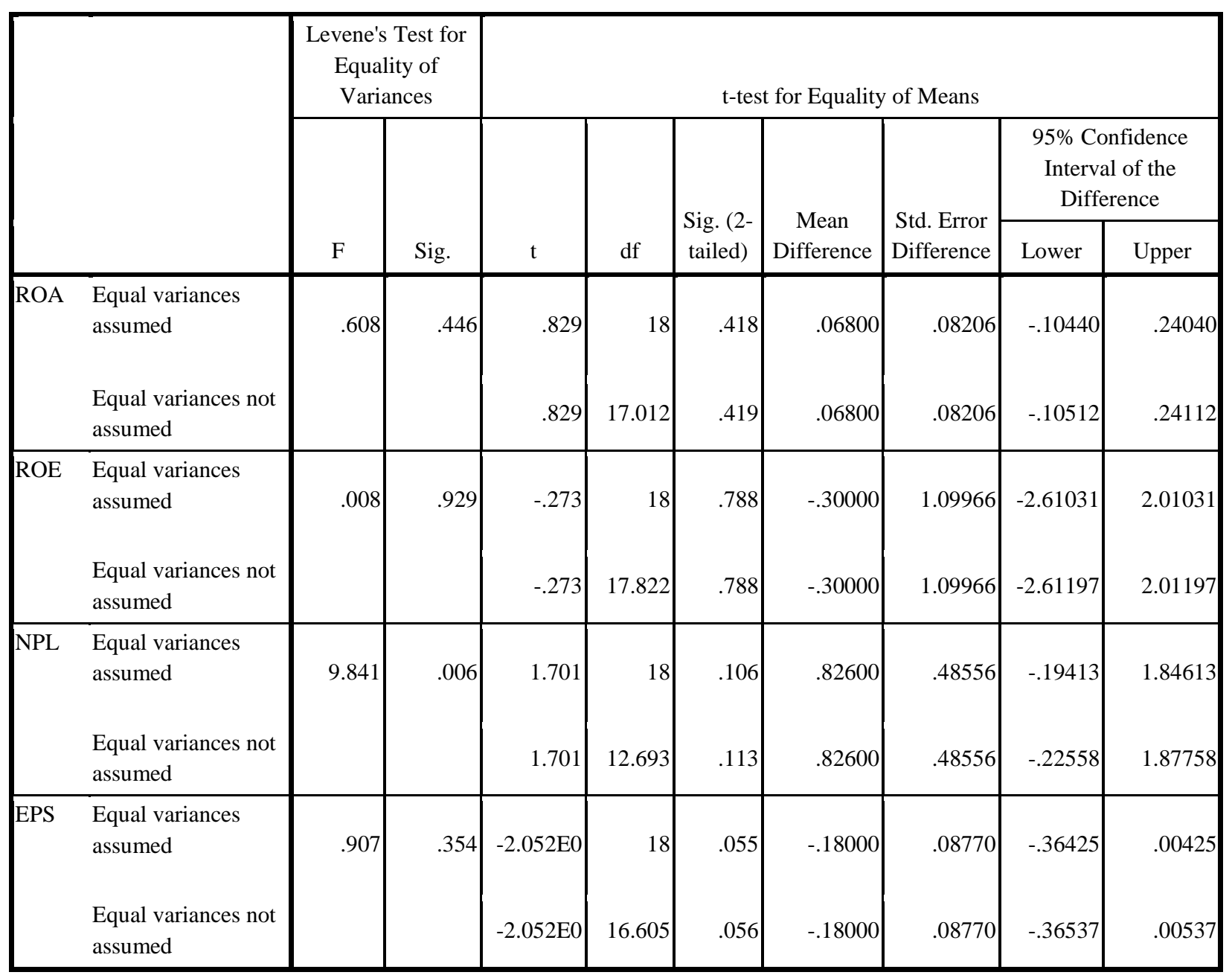

From table 2, we can observe that the significance value for $\mathrm{ROA}=0.418, \mathrm{ROE}=0.788, \mathrm{NPL}=0.113, \mathrm{EPS}=0.055$ all are greater than the significance value at $1 \%$ and $5 \%$ which means we have to accept the null hypothesis that there is 
no difference in performance in all the selected measures of performance between the Joint Venture and State Owned. Their performances are the same.

\section{Implications}

A lot of reforms have been done in the country with regards to state-owned enterprises, the reforms were aimed at opening up and eliminating the major problems which were causing the state-owned to underperform, these reforms can greatly explain why our results have indicated that the performance of state-owned and the joint venture is the same. The myth that was back in the days believing that state-owned had problems of inefficiencies is changing. The State-owned has finally caught up to the Joint Venture it can be because of the following improvements done Eradication of the agency problem by listing the company in the stock market is one of the ways. There is a separation of ownership and control, and the managers are now responsible for the performance of the company's shares in the stock market so they have to work hard for the interests of all the stakeholders. They now have the goal of maximizing shareholders wealth just like other firms.

Putting in place the performance measures and goals to motivate managers by aligning the executives incentives with the desires of the share holders, they have now shareholders annual general meetings where they have to explain their activities and their accomplishment for the whole year and a board of directors where some of them are not form the company to evaluate the management performance and they have stock options as rewards for reinforcing positive performance. Decentralization by giving the rights of decision making about the firm to the managers so they can decide how to use the company's assets in the most efficient and effective manner that will bring more returns to the firm and lead to a superior performance.

Opening up of markets that has reduced the level of concentration and increased competition in the banking industries that has caused state-owned to struggle to improve their competitive advantage and be able to compete on value for they no longer dominate the market and a lot of them have been broken down, so they are no longer as big as they were.

\section{Conclusion}

The share reform structures in China have reduced agency problems, improved corporate governance, and this has led to an improved performance of state-owned. Our finds have revealed that the performance of State-owned firms and Joint venture is the same. The best way for a firm to excel is to continue to innovate and find ways to improve its competitive advantage so it can earn higher returns. The findings show how the transformation in the Chinese economy and reform have opened up the markets and thus increased competition which has forced state-owned banks to improve their efficiency and capitalize on their assets in the most productive ways. With the appropriate incentives available managers, have become more responsible to maximize shareholders wealth as their firms are being monitored on the stock markets and fetch a high price only when their performance is good.

\section{References}

- Berger .A.N, Clarke .G.R.G, R.Cull, L.Klapper, G.F.Udell, (2005). Corporate governance and bank performance: A joint analysis of the static, selection and dynamic effect of domestic, foreign, and state ownership. Journal of Banking and Finance, 29(8-9), 2179-2221

- Boubakri N., Cosset, J. and Guedhami, O. (2005). Liberalization, corporate governance and Performance of privatized firms in developing countries. Journal of corporate finance, 11(5), 767-790

- Cho, D., Huang, F., 2010. A study on the corporate governance of China's state-owned enterprises: focus on the role of Baosteel CCP Organization. Academy Studies in International Business, 10(2), 5-9

- Ding, Y., Zhang, H., Zhang, J (2007). Private vs State Ownership and Earnings Managements: Evidence from Chinese listed companies. Journal of Corporate governance, 15(2), 223-238

- Fauzi, H. (2007). Corporate Social Responsibility and Financial Performance: Empirical Evidence from American Companies. Globsyn Management Journal, Revised Edition

- Jensen, M., Meckling, W. (1976). Theory of the firm: Managerial Behavior and Agency Costs, and Ownership structure. Journal of Financial Economics, 3, 305-360 
- La Porta, R., Lopez-de-Silanes, F., Shleifer, A., Vishny, R., (2002). Investor Protection and Corporate Governance. Journal of Financial Economics, 58, 3-27

- Ng, A., Yuce, A., Chen, E., (2008). Determinants of State Equity Ownership, and its effect on Value/Performance: China's Privatized Firms. Pacific-Basin Financial Journal, 17(4), 413-443

- Wang, K., Xiao, X., (2009). Ultimate government control structure and fair value: Evidence from Chinese listed companies. China Journal of Accounting Research, 2(1), 13-50

- Wei, Z.B., Varela. O, (2003). State equity ownership and firm market performance: Evidence from China's newly privatized firms. Global Finance Journal, 14, 65-82

- Xu, X., Wang, X., (2006). Corporate governance, ownership of the largest shareholder, and firm performance. China Accounting and Finance Review, 8(1), 145-184 